\title{
Influence of annual weather on growth of pedunculate oak in southern Sweden
}

\author{
Igor DRobyshev ${ }^{1 *}$, Mats NikLasson ${ }^{1}$, Olafur EGGERTSSON $^{2}$, Hans LINDERSON $^{2}$, Kerstin SONESSON $^{4}$ \\ ${ }^{1}$ Southern Swedish Forest Research Centre, PO Box 49, SLU, Alnarp, S-230 53 Sweden \\ ${ }^{2}$ Iceland Forest Research Station Mogilsa, 116 Reykjavik, Iceland \\ ${ }^{3}$ Laboratory for Wood Anatomy and Dendrochronology, Department of Quaternary Geology, Lund University Sölvegatan 12, Lund, S-223 62 Sweden \\ ${ }^{4}$ Malmö University, Teacher Education, Malmö, S-205 06 Sweden
}

(Received 22 November 2007; accepted 15 February 2008)

\begin{abstract}
-
- A network of oak (Quercus robur L.) chronologies containing 49 sites and 635 single trees was analysed to identify weather variables affecting annual tree-ring increment dynamics in southern Sweden during 1860-2000.

- We analysed (1) the growth response of oak to non-extreme weather, and (2) the temporal and spatial patterns of regional growth anomalies (pointer years) and associated climatic extremes resolved on a monthly scale.

- Growth was controlled by precipitation in the current (June-July) and the previous growing season (August) in $48 \%$ and $22 \%$ of all sites, respectively. Temperature during July of the current year and August of the previous year was negatively correlated with growth in 29\% and 43\% of the sites, respectively. Growth was positively correlated with temperature in October of the previous season in $72 \%$ of the sites. The most extensive growth anomaly occurred in 1965 and was probably caused by intrusion of cold Arctic air masses into the region at the end of March that year.

- During climatically non-extreme years, oak growth is driven mostly by the dynamics of summer precipitation. Many of the negative growth anomalies, however, were associated with temperature extremes. Southern Swedish oak pointer years tend not to coincide with the pan-European oak pointer years.

climatic variability / dendroecology / extreme events / hardwood / Scandinavia

Résumé - Influence de la variabilité interannuelle de climat sur la croissance du chêne pédonculé dans le Sud de la Suède.

- Une série de chronologies de chênes (Quercus robur L.) comprenant 49 stations et 635 arbres individuels a été analysée pour identifier les variables climatiques affectant la dynamique de croissance annuelle des cernes dans le Sud de la Suède, pendant la période 1860-2000.

- Nous avons analysé (1) la réponse de croissance des chênes aux évènements météorologiques non extrêmes et (2) les patrons temporels et spatiaux des anomalies régionales de croissance (années indices) et les extrêmes climatiques associés au pas de temps mensuel.

- La croissance était contrôlée par les précipitations de la saison de végétation (juin-juillet) et les précipitations de la saison de végétation précédente (août), respectivement dans $48 \%$ et $22 \%$ de toutes les stations. Les températures du mois de juillet de la saison de végétation et du mois d'août de l'année précédente étaient corrélées négativement avec la croissance, respectivement dans $29 \%$ et $43 \%$ des stations. La croissance était corrélée positivement avec la température du mois d'octobre de l'année précédente dans $72 \%$ des stations. L'anomalie de croissance la plus considérable est arrivée en 1965 et a été causée probablement par l'intrusion de masses d'air froid arctique dans la région, à la fin du mois de mars.

- Pendant les années climatiquement non-extrêmes, la croissance du chêne est principalement commandée par la dynamique des précipitations estivales. Cependant, beaucoup d'anomalies négatives de croissance ont été associées avec des extrêmes de température. Les années indices du Sud de la Suède ont tendance a ne pas coïncider avec les années indices pan-européennes.
\end{abstract}

Variabilité climatique / dendroécologie / évènements extrêmes / feuillus / Scandinavie

\section{INTRODUCTION}

Pedunculate oak (Quercus robur L.) is one of the main species for dendrochronology in Europe (Baillie et al., 1983; Briffa and Matthews, 2002; Kelly et al., 2002; Sass-Klaassen and Hanraets, 2006; Schweingruber, 1996). While studies on climate forcing of oak growth are common in continental and Western Europe, few studies of this type have been done in Sweden (Bartholin, 1975; Drobyshev et al., 2007c). Dendroclimatic studies have demonstrated the complexities associated with the growth response of pedunculate oak to climate. Summer drought reportedly has a negative effect on oak growth in Britain (Bridge and Winchester, 2000; Bridge et al.,

* Corresponding author: Igor.Drobyshev@ess.slu.se
1996; Pilcher and Gray, 1982), central and eastern Europe (Girardin et al., 2004; Osipov and Selochnik, 1989; Siwecki and Ufnalski, 1998), France (Levy et al., 1992), and southern Europe (Corcuera et al., 2004). A special case was oaks growing in currently extinct natural mire woodlands of NW Europe, where growth was apparently negatively related to the amount of precipitation during the growth season (Sass-Klaassen and Hanraets, 2006). Harsh winter and spring frost has also been noted as a factor that has a negative effect on oak growth in different parts of Europe (Osipov, 1989; Ståål, 1986; Thomas et al., 2002).

A study of pan-European oak pointer years was able to link them with periods of temperature and precipitation anomalies controlled by the North-Atlantic and Arctic circulation 
patterns (Kelly et al., 2002; Mares et al., 2002). Positive growth anomalies were associated with extended periods of increased soil-water availability, resulting from an easterly migration of the Icelandic Low, while negative anomalies were related to periods of lower air temperatures and reduced soil moisture, due to enhanced anticyclonic activity across Europe in those years. Many of these studies, however, focused only on the effects of extreme climatic periods, with no comparison being made between climatic controls over growth during climatically non-extreme and extreme seasons.

In southern Sweden, pedunculate oak reaches its northern European distribution range (Dahl, 1998), mixing both with conifer and deciduous species in several forest types. Oak colonised this part of Fennoscandia around 6000 BC (Brewer et al., 2002) and currently grows in a variety of habitats, including wooden pastures and mostly mixed closed-canopy stands. In this region oak is an important tree species, both commercially (Ståål, 1986) and as a part of the natural ecosystems, supporting species diversity of a variety of organism groups (Ranius and Hedin, 2001). Due to its importance for practical forestry and nature conservation in southern Scandinavia, modelling oak growth and its geographic distribution is often undertaken in the context of future climate variation (Prentice et al., 1991).

The general aim of this study was to quantify climategrowth relationships in pedunculate oak in southern Sweden. This was done through analysis of (a) the annual variation in tree-ring increment and (b) the spatial and temporal patterns in the occurrence of pointer years, i.e. years with extremely low or high growth (Schweingruber and Nogler, 2003). While tree growth over decadal or centurial timeframes usually represents response to non-extreme annual weather, pointer years are typically induced by climatic anomalies on the scale of months, weeks or even days. Such climatic anomalies are often caused by abrupt changes in atmospheric circulation patterns (Fritts, 1976). In this study we first analysed growth response of oak to monthly temperature and precipitation on the scale of single forest stands distributed over the whole area with oak occurrence in southern Sweden (Fig. 1). Then, data from all sampled trees was used to identify years with regional annual growth anomalies. Weather conditions were evaluated for the presence of climatic extremes in temperature and precipitation, resolved on a monthly scale. From all pointer years identified, we selected those with the best available growth and weather data in order to map the spatial patterns of the growth anomaly and climatic extremes in an attempt to identify the likely cause of pointer years. We linked the results of our study to the discussion of growth-climate interaction in the future. Finally, we compared oak pointer years identified for southern Sweden with a list of pan-European oak pointer years published earlier (Kelly et al., 2002).

\section{MATERIAL AND METHODS}

\subsection{Study area}

The oak trees were sampled in southern Sweden, in a region that spans from $55^{\circ}$ to $60^{\circ} \mathrm{N}$ and $12^{\circ}$ to $19^{\circ} \mathrm{E}$ (Fig. 1). The mean an- nual temperature in this region ranges between $5{ }^{\circ} \mathrm{C}$ and $8{ }^{\circ} \mathrm{C}$. The mean temperature in January varies between $-4{ }^{\circ} \mathrm{C}$ and $0{ }^{\circ} \mathrm{C}$; and between $15{ }^{\circ} \mathrm{C}$ and $16{ }^{\circ} \mathrm{C}$ in July. There is a large precipitation gradient between the western (up to $1200 \mathrm{~mm} /$ year) and the eastern (500 $\mathrm{mm} /$ year) parts of the region and prevailing winds are typically westerly or southwesterly (Raab and Vedin, 1995). The growing season, defined as the period with average daily mean air temperature above $5{ }^{\circ} \mathrm{C}$, lasts for 180-240 days (Nilsson, 1996). Snow cover varies within the study region and typically occurs from midNovember to late March. The dominant soil type is till, which has a history of glacial dynamics and was formed on sandy and stony moraines, and some areas are covered by richer clayed till from sedimentary limestone (Fredén, 2002).

The region stretches over both the nemoral and hemi-boreal phytogeographical zones (Ahti et al., 2004) and since a major part of the study region is a transition zone between the boreal and temperate biomes, both coniferous and deciduous trees are common. Norway spruce (Picea abies (L.) Karst.) and Scots pine (Pinus sylvestris L.) are the main coniferous species, while oak (Quercus robur L. and Q. petraea Mill.) and beech (Fagus sylvatica L.), together with smallleaved species (downy birch, Betula pubescens Ehrh. and aspen, Populus tremula L.), form the most prominent deciduous element of the vegetation.

Study sites were selected to reflect a range of site types and stand ages, as well as to cover most of the oak distribution range in southern Sweden ( $n=49$, Fig. 1$)$. The site network is a product of newly established chronologies and the chronologies provided by the laboratory for wood anatomy and dendrochronology, Lund University, Sweden (Bartholin, 1975). It should be noted, however, that this network of sites cannot be considered 'representative' in an objective manner, since site selection was non-random. However, the large number of sites sampled and trees analysed (total $n=635$ ) should ensure that the results are representative for the region of southern Sweden.

\subsection{Weather data and mapping of weather extremes}

Average monthly air temperature, sum of monthly precipitation and average lowest monthly temperature were obtained from 64 SMHI climate stations distributed over the region (Tab. I). The homogeneity of climatic data was checked through the Mann-Kendall statistical test for randomness on each paired station set, with one station being Nordklim station with the homogeneity of the data ensured (Tuomenvirta et al., 2001). In years when oak growth anomalies were present (see the following sub-section), monthly weather anomalies were identified from Nordklim climate data for the period 1860-2000. A monthly weather anomaly was defined as a period with the weather variable value located outside the central $90 \%$ of its longterm distribution. For each selected pointer year climatic extremes were identified for the period "preceding year August" - "current year August". Prior to analyses, weather variables were transformed into residuals from long-term distribution.

Spatial patterns of climatic extremes associated with three of the most recent pointer years were mapped and prediction maps were produced using the krigging routine method in the Geostatistical Analyst module of ESRI ArcMap 8.3 (Anonymous, 2002). The routine utilised a weighted monthly value for each respective month:

$$
X_{i w}=\frac{\left(X_{i}-X_{\text {mean }}\right)}{S D},
$$




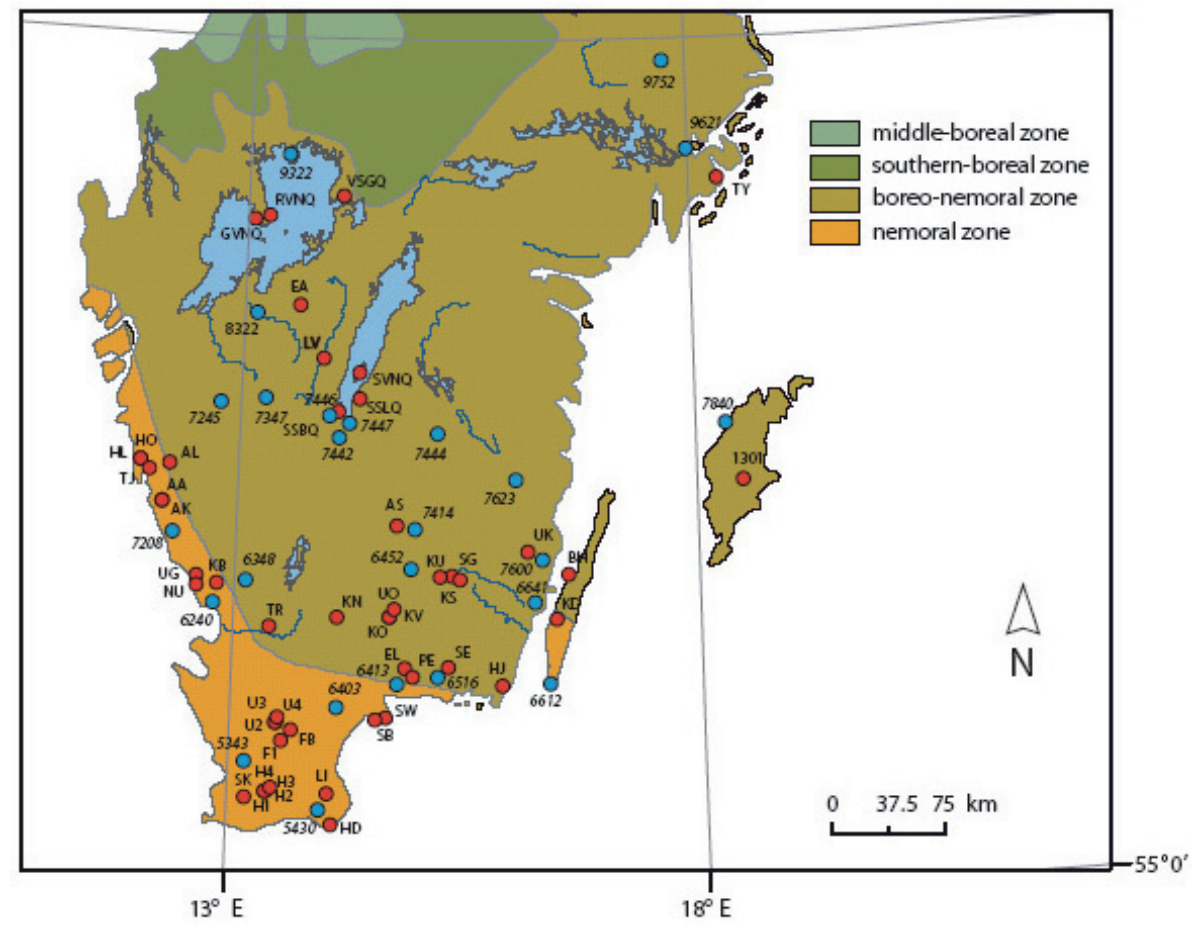

Figure 1. Location of sites with oak chronologies (black dots) and climatic stations (white dots, number in italics). Boundaries of vegetation zones are according to the Swedish National Atlas (SNA, 2001). Northern border of the boreal-nemoral zone roughly corresponds to the northern distribution limit of oak.

where $X_{i w}$ is the weighted monthly value for a particular month and station, $X_{i}$ is the original monthly value $\left({ }^{\circ} \mathrm{C}\right.$ for temperature, $\mathrm{mm}$ for precipitation), and $X_{\text {mean }}$ and SD are mean and standard deviation values, respectively, for a particular month, over the whole observation period. The resulting maps were rasterised and then reclassified into five classes representing various levels of departure from the long-term mean for a particular month. Reclassification was done using the natural breaks method (Spatial Analyst module of ESRI AcrMap 8.3).

\subsection{Tree-ring analyses}

On each site a study plot was established $\left(20 \times 10\right.$ or $\left.25 \times 15 \mathrm{~m}^{2}\right)$ and cores were randomly taken from between 10 and 31 trees using an increment borer. Such variation in the amount of trees sampled and, particularly, the low number of trees sampled at several sites, was due to the limits imposed by the sampling permits. Core samples were taken at breast height along two radii from each tree, and after they were dried and mounted on wooden plates, they were polished using a belt sander, with up to a 400 grit band. The cores were measured using an ANIOL measuring stage controlled by the software CATRAS (Aniol, 1983). The two core samples were averaged into single-tree chronologies, which were subsequently cross-dated and verified by using signature years (Stokes and Smiley, 1968), and the CATRAS (Aniol, 1983) and COFECHA (Grissino-Mayer et al., 1997) computer programs. After cross-dating and measuring of the samples, some of them were filtered out due to inconclusive dating and/or presence of tension wood. The number of sampled trees fi- nally included in the analyses varied between 7 and 30 per site (with the mode being 15 trees per site).

Residual chronologies resulting from autoregressive modelling of the site chronologies in the ARSTAN program (Grissino-Mayer et al., 1997) were used to evaluate climate-growth relationships through response function analyses (Cook and Kairiukstis, 1990). Response function coefficients, in contrast to the common correlation coefficients, were produced using principal component regression analysis (Biondi and Waikul, 2004), which removes autocorrelation present in the climatic data. The response function coefficients were tested using the bootstrap method (Efron and Tibshirani, 1994) for their statistical significance. This included random re-sampling of the original dataset with replacement, generating a statistical distribution of a response coefficient, and calculating its $2.5 \%$ and $97.5 \%$ distribution limits. Finally, the value obtained from the original dataset was compared with the bootstrap-generated distribution limits to assess the significance of the coefficient's departure from zero at the 0.05 probability level. We analysed the period between July of the previous season and the current year's August. Preliminary analyses with varying periods confirmed that increasing the number of previous season months would have little effect on the outcome of analyses. We, therefore, attempted to limit the number of months analysed to ensure the statistical stability of the final results.

The analyses were performed, with the help of the DendroClim program (Biondi and Waikul, 2004), using mean monthly temperature and the total sum of monthly precipitation from the nearest climate station. All tests used a significance threshold of $5 \%$.

A pointer year is generally understood as a year with particularly narrow rings in the majority of trees sampled within a site or an area 
Table I. Climatic features during the regional pointer years in oak in southern Sweden. Climatic extremes shown were selected for the previous year July-current year August. Years shown had growth anomalies in $>15 \%$ of all trees in the dataset. Each year was replicated by at least 150 trees and each pointer year by at least 50 trees. Months shown had the values of weather variables, located outside the central $90 \%$ part of respective distributions, with the actual percentiles shown in brackets. PY - previous year. $n$ refers to the number of trees expressing a particular pointer year. ND - no data available.

\begin{tabular}{|c|c|c|c|c|c|c|}
\hline \multirow{2}{*}{ Year } & \multicolumn{2}{|c|}{ Number of trees } & \multirow{2}{*}{ Type of pointer } & \multirow{2}{*}{ Average monthly temperature } & \multirow{2}{*}{ Sum of monthly precipitation } & \multirow{2}{*}{ Lowest minimum temperature } \\
\hline & $\%$ & $n$ & & & & \\
\hline 1965 & 32.4 & 191 & Negative & July - (3.5\%) & - & $\begin{array}{l}\text { March }-(3,4 \%) \\
\text { July - }(0.8 \%)\end{array}$ \\
\hline 1868 & 26.1 & 60 & Negative & December PY - $(0.01 \%)$ & - & ND \\
\hline 1940 & 23.7 & 130 & Negative & $\begin{array}{l}\text { August PY }+(97.2 \%) \\
\text { October PY }-(3.7 \%) \\
\text { February }-(1.9 \%) \\
\text { March }-(4.2 \%)\end{array}$ & - & $\begin{array}{l}\text { August PY }+(99.1 \%) \\
\text { February }-(2.8 \%) \\
\text { March }-(2.6 \%) \\
\text { August }-(1.9 \%)\end{array}$ \\
\hline 1992 & 20.1 & 122 & Negative & $\begin{array}{l}\text { July PY + }(98.9 \%) \\
\text { January }+(97.6 \%) \\
\text { May }+(99.4 \%) \\
\text { June + }(99.9 \%)\end{array}$ & June $-(0.001 \%)$ & July $+(95.6 \%)$ \\
\hline 1882 & 19.4 & 60 & Positive & - & - & ND \\
\hline 1956 & 17.9 & 103 & Negative & $\begin{array}{l}\text { August PY }+(97.9 \%) \\
\text { September PY }+(97.2 \%) \\
\text { February }-(4.2 \%)\end{array}$ & $\begin{array}{l}\text { July PY }-(2.1 \%) \\
\text { November PY }-(1.7 \%) \\
\text { December PY }+(97.8 \%)\end{array}$ & February - $(4.3 \%)$ \\
\hline 1902 & 17.2 & 70 & Negative & $\begin{array}{l}\text { October PY + }(95.6 \%) \\
\text { July }-(0.08 \%)\end{array}$ & $\begin{array}{l}\text { July PY }-(0.049) \\
\text { February }-(0.056)\end{array}$ & - \\
\hline 1860 & 16.5 & 33 & Positive & - & - & ND \\
\hline 1947 & 16.5 & 93 & Negative & - & $\begin{array}{l}\text { September PY + }(99.3 \%) \\
\text { May }-(0.7 \%) \\
\text { August }-(1.9 \%)\end{array}$ & $\begin{array}{l}\text { Sept. PY + }(95.5 \%) \\
\text { March }-(1.5 \%)\end{array}$ \\
\hline 1869 & 16.0 & 38 & Negative & - & $\begin{array}{l}\text { March - }(1.4 \%) \\
\text { July - }(1.4 \%)\end{array}$ & ND \\
\hline
\end{tabular}

(Schweingruber, 1996). In this study a pointer year was defined as a year when ring width was below $5 \%$ or above $95 \%$ of the ring width distribution of a single tree. Pointer years were selected by using the XTRLST routine of the Dendrochronological Program Library (Holmes, 1999). Strength (i.e. intensity) of a pointer year was assessed by dividing the number of trees within a pointer year by the number of trees in the dataset which were alive when the pointer year occurred.

The XTRLST procedure was used to assess every calendar year during the period $1860-2000$ on all sites $(n=635)$ but only pointer years expressed in more than $15 \%$ of the total oak population sampled were included in analyses $(n=10)$. Of these, the three most recent pointer years were selected and their spatial patterns in southern Sweden were analysed to determine their climatic controls. For this purpose a $4 \times 4$ cell grid was made over the study area (excluding sites 1620 and TY, which were located too far north) with the length corresponding to the longitudinal extent of the sample area. Grid dimensions $\left(105 \times 105 \mathrm{~km}^{2}\right)$ were chosen so as to obtain sub-regional estimates of pointer year percentages and to ensure there was a reasonable number of trees within each grid cell. The number of trees varied between 31 and 114, with a mean of 61 trees per year and per grid cell. In total, there were nine cells, each representing between 3 and 10 sites. Data for cells 6 and 7 was combined during the analyses. Values of weather variables for a cell were then calculated as the average of site-specific values within that cell. These values were, in turn, obtained by krigging of climate stations' data.

\section{RESULTS}

The southern Swedish oak chronology developed in this study extended back to 1640 and the replication (number of trees contributing to the chronology values in a particular year) for a single year has exceeded 100 trees since 1818 . The replication exceeded 280 trees during the period 1880-2000. The decline in replication values occurring in the late 1990s was due to the fact that the year 1996 was a termination date for the datasets provided by the Laboratory for Wood Anatomy and Dendrochronology, Lund University. During 1860-2000 the mean cambial age (the mean age of the trees contributing to the chronology in a particular year) steadily increased from 57 to 128 years. It is possible that the position of the trees within the stand changed throughout this period, which may explain the growth response to environmental variation. The absolute difference in average cambial age between 1860 and 2000 was 71 years (Fig. 2), which we considered to be relatively moderate as compared with 140 years of chronology span. 


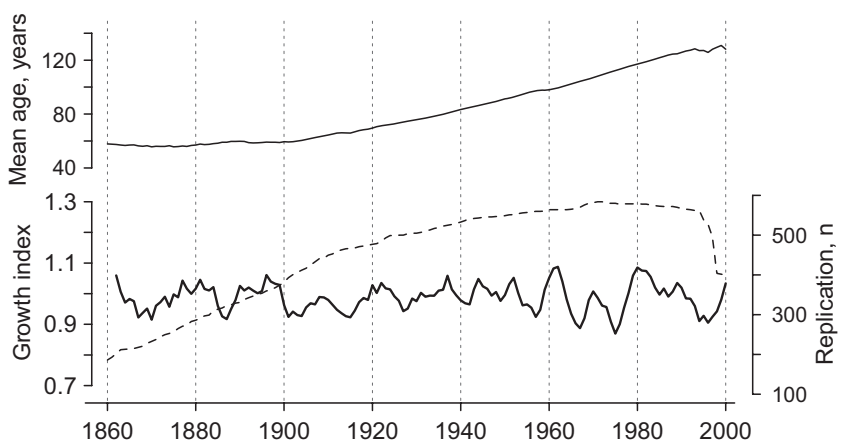

Figure 2. Regional oak chronology (1860-2000) from southern Sweden (thick line, lower graph) and its replication (dashed line). Change in the average age of trees is indicated in the upper graph.

\subsection{Response function analyses}

Current year July temperatures and previous year August temperatures had a negative impact on the growth in 29 and $43 \%$ of sites, respectively (Fig. 3). Growth was strongly controlled by the amount of precipitation in the current (June-July, in $48 \%$ of all sites) and the previous growing seasons (August, $22 \%$ of all sites) and by the temperature in October of the previous year ( $72 \%$ of sites).

\subsection{Growth pattern, identification of pointer years and weather conditions}

Periods with pronounced positive growth anomalies occurred around 1890-1900, 1920-1925, 1958-1964 and 19781985. Two positive pointer years (1882 and 1860) were not associated with either temperature or precipitation extremes. In 1860 , the sum of precipitation reached values above the 93\% percentile for June (average for all stations $-90.6 \mathrm{~mm}$ ) and above the $94 \%$ percentile for August $(117.1 \mathrm{~mm})$. The long-term mean and SD for June precipitation were $52.2 \pm$ $28.9 \mathrm{~mm}$, and for August precipitation $-73.4 \pm 40.1 \mathrm{~mm}$. July of 1860 , though, was relatively dry $(38.9 \mathrm{~mm}$, below $12 \%$ of the distribution; long-term average and SD $70.1 \pm 36.1 \mathrm{~mm}$ ). The summer temperature during this year, instead, was close to average (between 27\% and $47 \%$ of distributions of long-term mean monthly values). In 1882, mild summer temperatures (within $43-76 \%$ of the respective distributions) coincided with excessive precipitation. During each summer month the sum of precipitation stayed above $83 \%$ of all the values recorded for a particular month over the studied period: June $(85.3 \mathrm{~mm})$, July $(107.6 \mathrm{~mm})$ and August $(115.7 \mathrm{~mm})$.

Periods with growth decreases occurred in 1885-1889, 1902-1907, 1914-1917, 1955-1957, 1965-1967, 1973-1977 and 1992-1998. Negative pointer years occurred in 1992, 1965, 1956, 1947, 1940, 1902, 1869 and 1868. The most pronounced negative pointer year was in 1965 and was expressed most strongly in the north-western part of the study area.

Of the 37 monthly weather extremes associated with pointer years, 16 had mean temperature anomalies, 11 had precipitation anomalies and 10 had lowest temperature anomalies.

\section{A. Average monthly temperature}

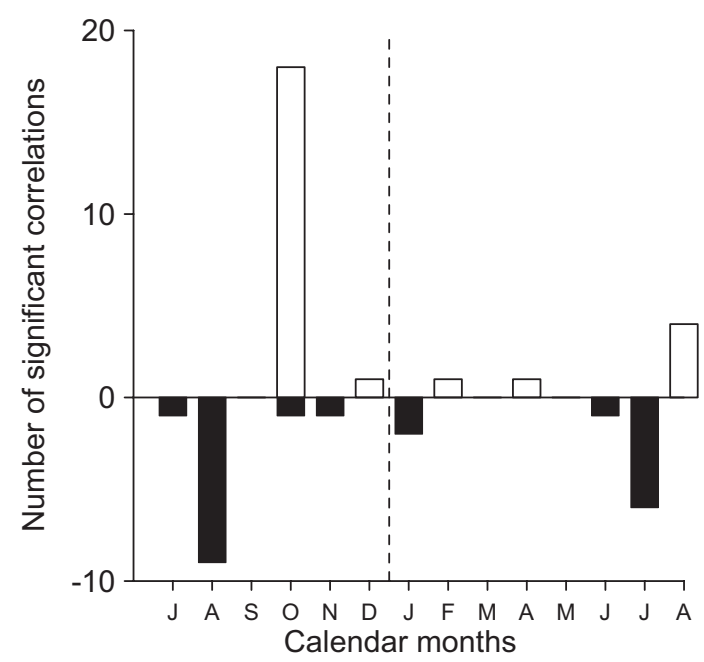

\section{B. Sum of monthly precipitation}

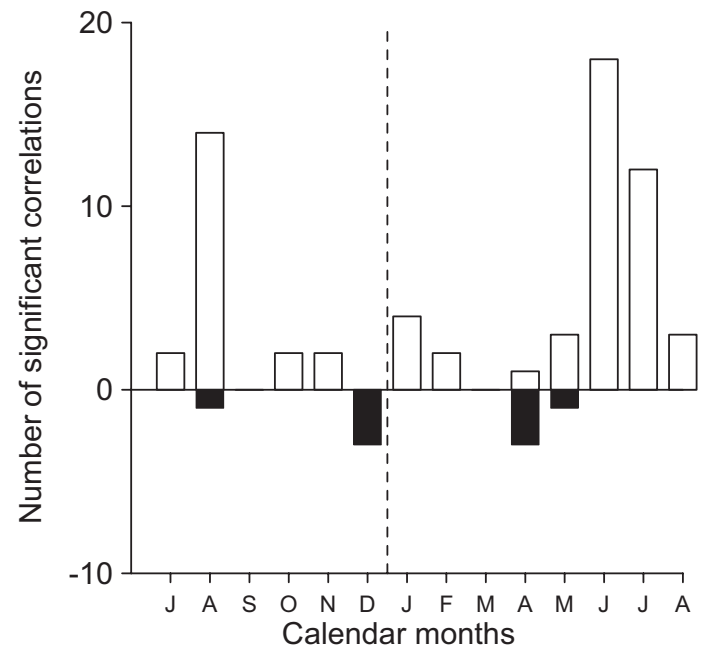

Figure 3. Correlations between monthly weather variables and oak growth at 49 sites in southern Sweden. Response function analysis was carried out on each site chronology and climatic data from the nearest weather station for the period previous year July-current year August. Dotted line marks the end of the calendar year. Data - number of significant response function coefficients for each month and for each weather variable.

Assuming that occurrence of a pointer year and climatic extremes (a month with value of a weather variable outside the central $90 \%$ of its long-term distribution) are independent of each other, the expected frequency of a simultaneous occurrence of these two events can be calculated simply by multiplying a weather extreme frequency by a pointer year frequency. Weather extreme frequency was, by our definition, 10 in 100 years, or 14 in the whole 140-year study period; the frequency of pointer years identified was $10 / 140=0.07$. Multiplying these probabilities would yield $0.14 \times 0.07 \approx 0.01$, or about one year within the time frame studied. In other words, a monthly extreme associated with a pointer year occurring 
A. 1992

1992

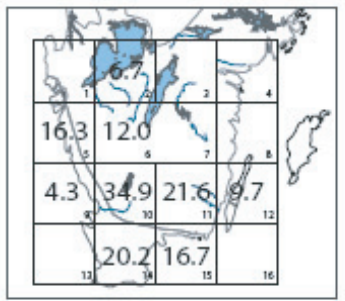

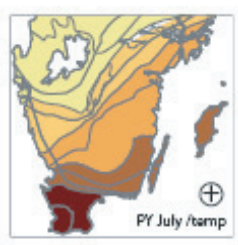
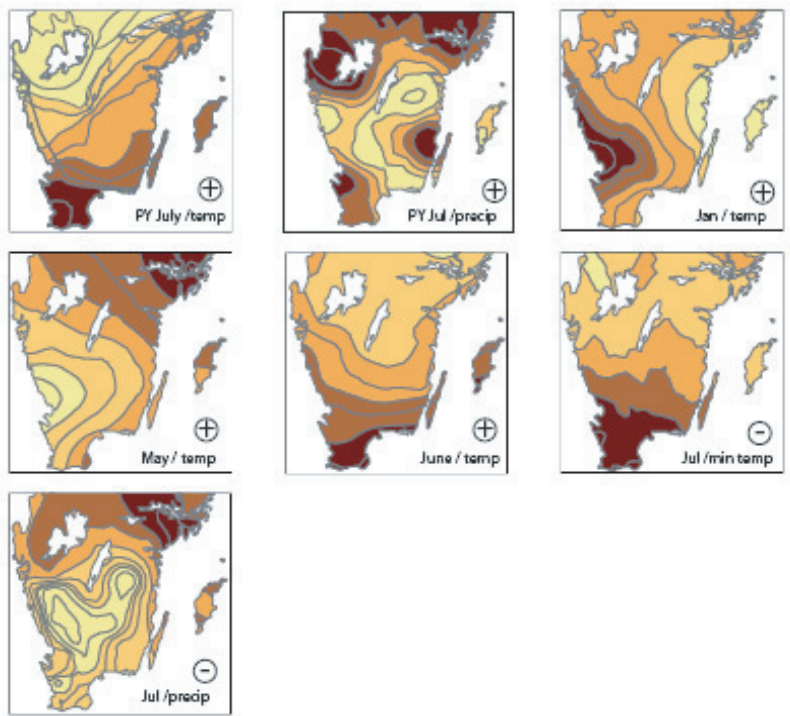

Figure 4. Mapping of spatial distribution of pointer years and weather extremes recorded over a period (previous year July - current year August) during the most recent negative pointer years (1992, 1965 and 1956). The type of weather extreme (positive or negative anomaly) is indicated as a plus or a minus in the lower right corner of the respective map. The top map represents percentages of trees recording pointer years in each of nine cells across the studied region. Colour/grey coding is a product of reclassification of the krigged weather data from available climate stations, with darker colours representing higher absolute values. It follows that under conditions of a positive weather anomaly, the most extreme weather is represented by darker colours, and during negative growth anomaly - by lighter colours. "PY" stands for "previous year".

more than once from 1860-2000 would indicate a higher-thanexpected probability of a simultaneous occurrence of a pointer year and a climatic extreme during that month. For the lowest monthly temperatures, with no data available before 1900 , the adjusted probability was even lower: $0.05 \times 0.06=0.003$ (number of years with the lowest temperature dropping below $5 \%$ of its distribution multiplied by frequency of pointer years).

Negative anomalies of the March lowest temperatures were associated with the pointer years three times $(1965,1947$ and 1940), and negative anomalies of the lowest temperatures in
B. 1965

1965
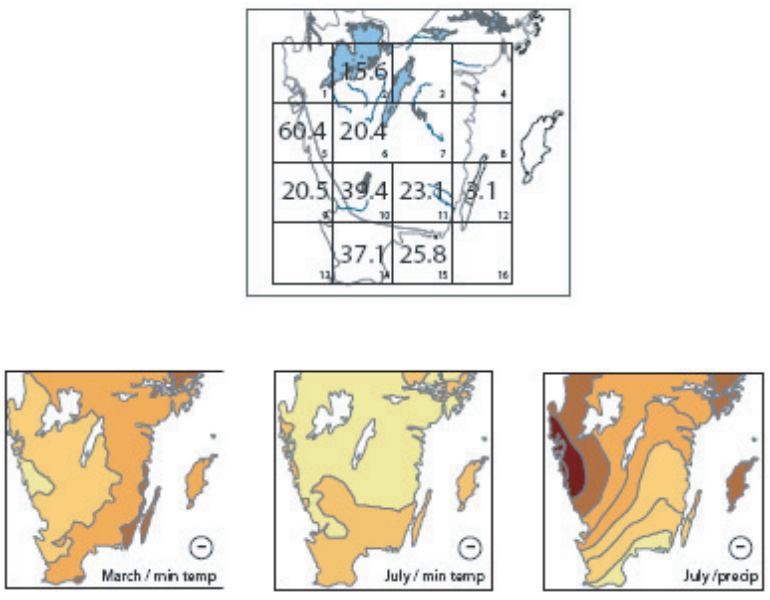

C. 1956

1956
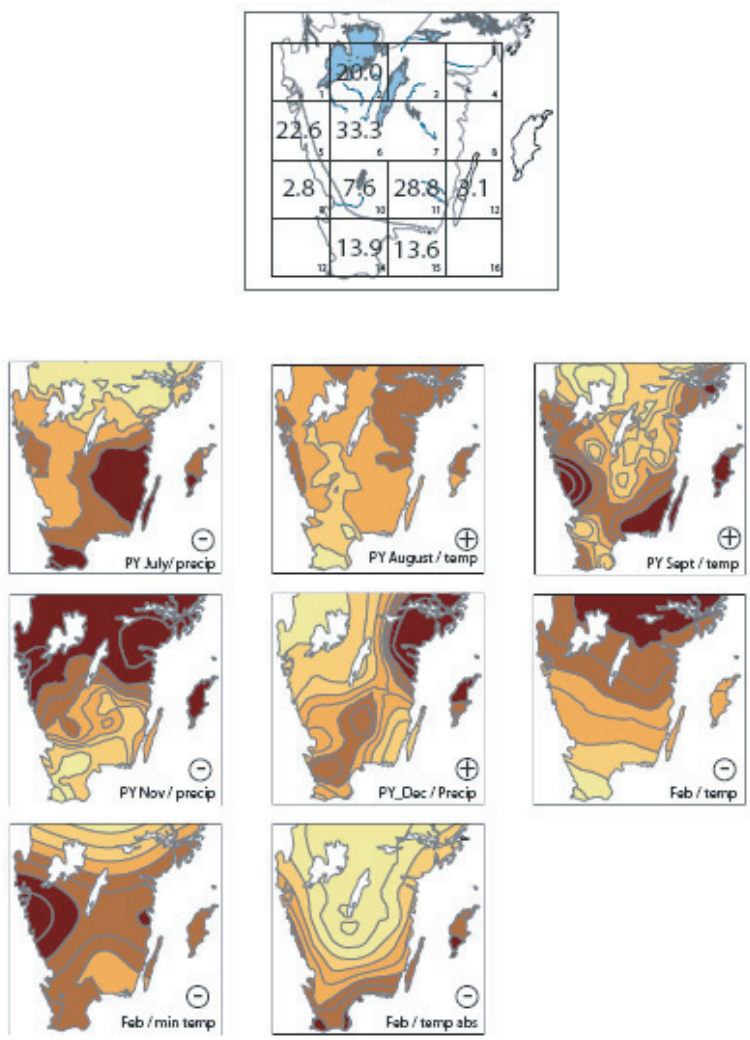

February were associated with the pointer years twice (1956 and 1940). Other monthly weather extremes associated with pointer years more than once were previous year August average temperatures (two positive anomalies, 1940 and 1956), previous year October temperatures (one positive, 1902, and one negative anomaly, 1940), February and July average temperatures (two negative anomalies each month; 1940 and 1956, 


\section{2}

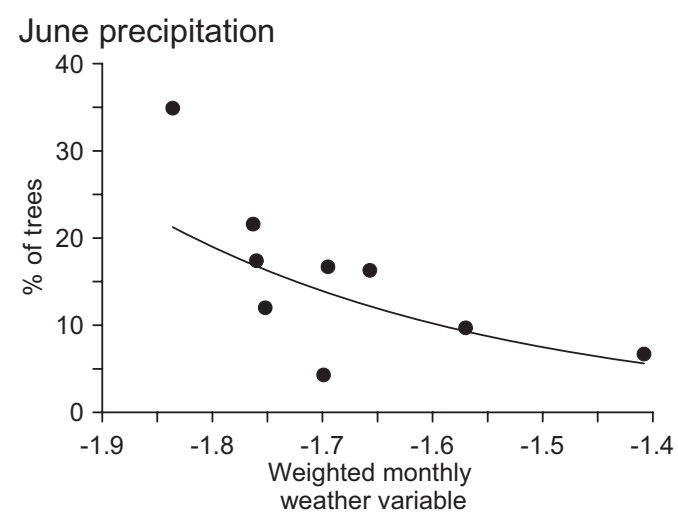

Previous year July precipitation

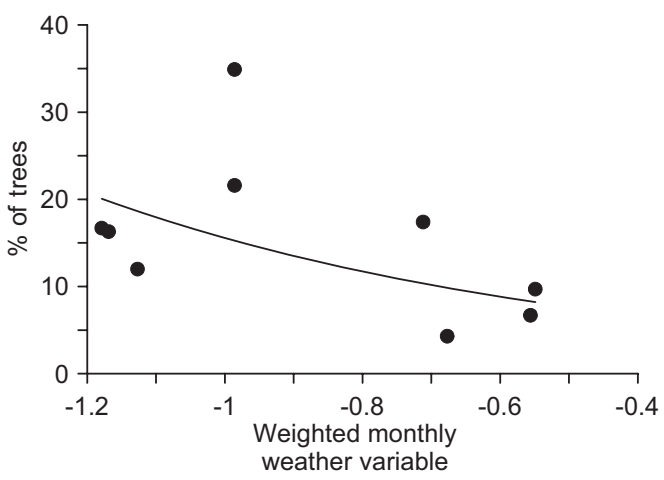

1965

Minimum temperature, March

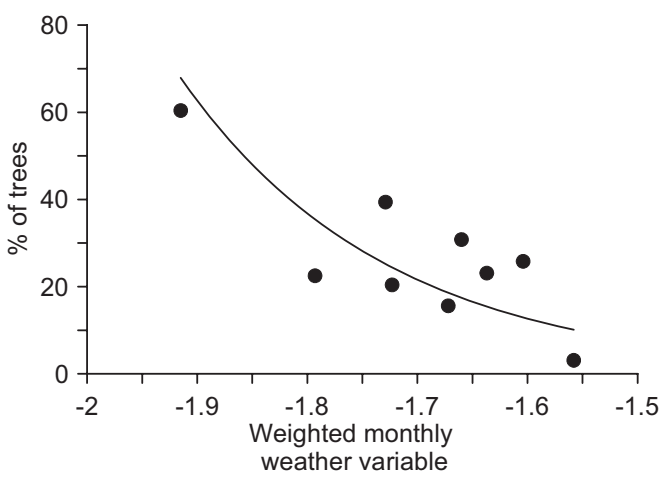

Previous year July temperature

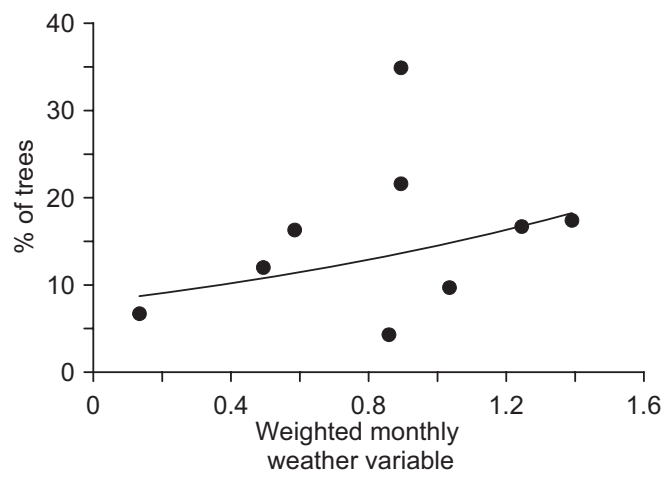

\section{6}

February temperature

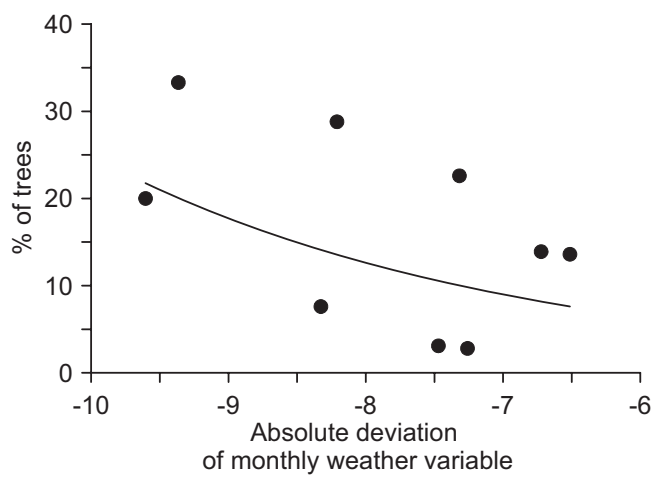

Figure 4. Percentage of trees expressing a pointer year ( $Y$ axis on the graphs), within a grid cell (see Fig. 4), as a function of strength of climate anomaly within that grid cell for the three most recent pointer years in southern Sweden. Selection of monthly variables is based on the results of non-parametric rank correlation analyses and bootstrap tests (see Tab. II). Fitting functions: $1992-$ June precipitation $Y=$ $\exp (-3.105 \times X) \times 0.071, R^{2}=39.3 \%$; previous year July temperature $Y=\exp (0.588 \times X) \times 8.054, R^{2}=13.0 \%$; previous year July precipitation $Y=\exp (-1.418 \times X) \times 3.772, R^{2}=34.1 \% ; 1965-$ minimum March temperature $Y=\exp (-5.33 \times X) \times 0.003, R^{2}=47.9 \% ; 1956-$ February temperature $Y=\exp (-0.339 \times X) \times 0.838, R^{2}=16.5 \%$. 
Table II. Correlation analyses of pointer year manifestation and weighted monthly weather extremes within nine sub-regions (grid cells) in southern Sweden for the three most recent pointer years. Stability of coefficients was tested by bootstrapping the original dataset 500 times and obtaining statistics of $r$ distribution. Location of each grid cell is shown in Figure 4 (krigged maps). PY: "previous year". In the case of a negative correlation, the percent of re-samples is the proportion of negative correlations out of the total amount of bootstrap runs $(n=500)$; in the case of a positive correlation it is the amount of positive coefficients. Asterisk indicates variables that showed the highest correlation with the spatial pattern of pointer years.

\begin{tabular}{|c|c|c|c|c|}
\hline \multirow{2}{*}{$\begin{array}{l}\text { Variable, type of extreme } \\
(+, \text { positive; }-, \text { negative })\end{array}$} & \multicolumn{4}{|c|}{$r$ Spearman } \\
\hline & Empirical rand its $p$ level & Re-sampled r,mean $\pm \mathrm{SD}$ & $\begin{array}{l}2.5 \% \text { and } 97.5 \% \text { thresholds } \\
\text { of re-sampled distribution of } r\end{array}$ & $\begin{array}{l}\% \text { of re-samples below/ } \\
\text { above zero threshold }\end{array}$ \\
\hline \multicolumn{5}{|l|}{1992 (negative) } \\
\hline PY_Temp July + * & $0.62 / 0.177$ & $0.46 \pm 0.270$ & $-0.05 / 0.82$ & 93.2 \\
\hline PY_Precip July + * & $-0.47 / 0.194$ & $-0.43 \pm 0.277$ & $-0.73 / 0.11$ & 88.6 \\
\hline Temp May + & $0.21 / 0.576$ & $-0.23 \pm 0.456$ & $-0.95 / 0.51$ & 32.6 \\
\hline Temp June + & $-0.11 / 0.433$ & $0.28 \pm 0.375$ & $-0.37 / 0.88$ & 23.2 \\
\hline Precip June - * & $-0.59 / 0.020$ & $-0.74 \pm 0.256$ & $-1.0 /-0.26$ & 98.0 \\
\hline MinTemp July - & $-0.03 / 0.286$ & $0.37 \pm 0.359$ & $-0.27 / 0.89$ & 15.4 \\
\hline Temp Jan + & $-0.54 / 0.765$ & $0.13 \pm 0.418$ & $-0.53 / 0.75$ & 39.4 \\
\hline \multicolumn{5}{|l|}{1965 (negative) } \\
\hline MinTemp March - * & $-0.47 \pm 0.205$ & $-0.43 \pm 0.346$ & $-1.0 / 0.33$ & 88.0 \\
\hline Temp July - & $-0.02 \pm 0.966$ & $-0.01 \pm 0.391$ & $-0.76 / 0.72$ & 51.6 \\
\hline MinTemp July - & $0.15 \pm 0.700$ & $0.18 \pm 0.435$ & $-0.63 / 0.95$ & 58.8 \\
\hline \multicolumn{5}{|l|}{1956 (negative) } \\
\hline PY Precip July - & $0.05 / 0.898$ & $0.06 \pm 0.405$ & $-0.76 / 0.82$ & 56.2 \\
\hline PY Temp Aug & $0.18 / 0.637$ & $0.18 \pm 0.376$ & $-0.60 / 0.89$ & 69.6 \\
\hline PY Temp Sept + & $-0.40 / 0.286$ & $-0.37 \pm 0.357$ & $-0.93 / 0.35$ & 82.8 \\
\hline PY Precip Nov - & $0.22 / 0.576$ & $0.15 \pm 0.332$ & $-0.56 / 0.62$ & 74.4 \\
\hline PY Precip Dec + & $-0.15 / 0.700$ & $-0.15 \pm 0.338$ & $-0.79 / 0.54$ & 69.0 \\
\hline Temp Feb - & $0.61 / 0.366$ & $0.29 \pm 0.307$ & $-0.49 / 0.73$ & 49.0 \\
\hline MinTemp Feb - & $0.13 / 0.732$ & $0.10 \pm 0.394$ & $-0.81 / 0.74$ & 61.4 \\
\hline MinTemp Feb (abs) -* & $-0.42 / 0.265$ & $-0.37 \pm 0.293$ & $-0.89 / 0.29$ & 87.8 \\
\hline
\end{tabular}

and 1902 and 1965, respectively), and the sum of the previous year's July precipitation (two negative anomalies: 1902 and 1956).

\subsection{Gridding monthly weather variables and oak pointer years}

The spatial pattern of pointer year manifestation was analysed for the three most recent pointer years (1992, 1965 and 1956) in the whole study region. For 1965, gridding the three climatic extremes that occurred that year (minimum temperature in March and July, and mean temperature in July) showed a correlation between the pattern of growth anomaly and the minimum temperature in March (Fig. 4). Bootstrapping the original dataset 500 times showed that in $88 \%$ of the datasets re-sampled, the rank correlation coefficient between weighted SD of the weather variable and percentage of trees within that pointer year was negative (Tab. II, Fig. 5). The pointer year of 1992 was expressed more in the central and southern parts of the study region. Of the seven climatic extremes gridded, the drought pattern in July, expressed as corresponding monthly values of temperature and precipitation, was the most consistent with the spatial pattern of growth anomaly during that year (Fig. 4, Tab. II). The pointer year of 1956 was more distinct in the northern part of the area (Fig. 4) but the spatial association with any of the seven identified climatic extremes remained unclear. Since the lowest absolute temperatures were associated with the northern part of the area (the pattern which was disrupted while converting data into weighted deviations from monthly means), the growth anomaly data was compared with the absolute deviations in minimum February temperatures to produce the highest absolute value of $r$ for that year (empirical $r=-0.42$ and mean re-sampled $r=-0.37$, Tab. II). This indicated that the spatial pattern of the negative growth anomaly in 1956 might be related to the pattern of low temperature spell that occurred in February that same year (Fig. 4).

\subsection{Comparison of pointer year manifestation and change in growth pattern}

The ratio between cumulative growth over three years prior and three years after a negative pointer year was calculated in order to test whether or not the strength of expression of a negative growth anomaly was related to an actual change in growth. A linear regression between this ratio and the percentage of trees expressing this pointer year $(Y=-1.274 \times$ $X+113.72$ ) accounted for $85.4 \%$ of the variation between two variables (Fig. 6). This suggested that pointer year manifestation (proportion of trees with the year in question as a pointer year) was closely correlated to oak growth for at least three years after the occurrence of a pointer year. 


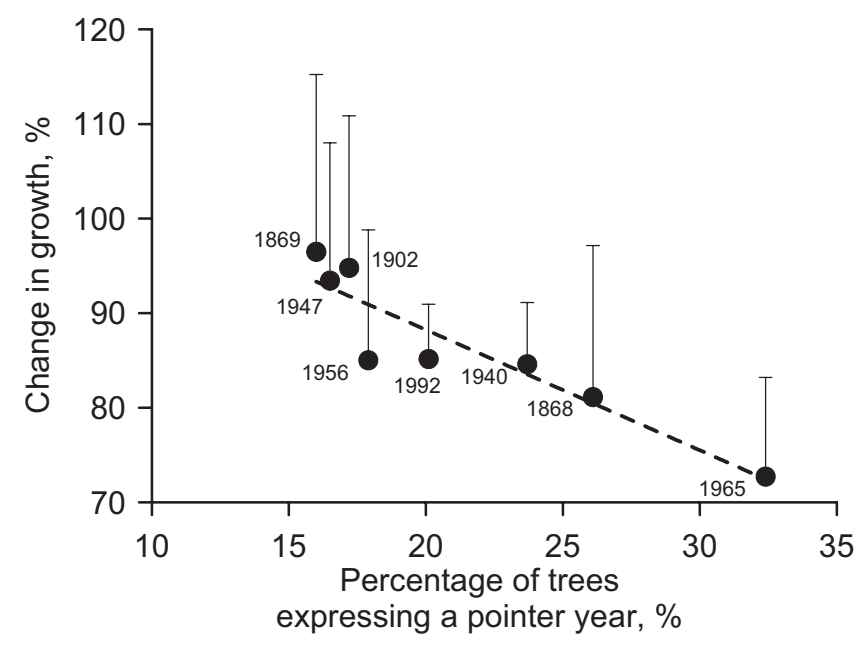

Figure 5. Differences (\%) in cumulative growth over three years before and after a negative pointer year ( $O Y$ axis), as a function of percentage of trees expressing this pointer year ( $O X$ axis). Change in growth was calculated as an average of nine values, each representing one of the grid cells (see Fig. 4) Error bar is one SD. Linear regression $(Y=-1.274 \times X+113.72$, dashed line) accounted for $85.4 \%$ of variation between two variables.

\section{DISCUSSION}

\subsection{Growth and monthly weather conditions}

In southern Sweden it is the water regime in the first two months of the summer which affects the oak growth the most during climatically non-extreme years, precipitation during the previous growth season also being of importance (Fig. 3). This is in agreement with the results of other European studies, which have shown a clear negative effect of summer water deficit on oak growth (Osipov, 1989; Tessier et al., 1994; Bridge et al., 1996; Siwecki and Ufnalski, 1998; Kelly et al., 2002). In addition, while higher summer temperatures had a negative impact on growth, it was not as pronounced as was the positive impact of precipitation (Fig. 3). Generally, European oak can sustain periods of prolonged drought due to a complex system of stomatal (Dickson and Tomlinson, 1996) and non-stomatal controls of carbon fixation (Epron and Dreyer, 1996). The clear negative association between growth and water deficit, however, points to reduced hydraulic conductance of shoots, and, as a result, limits stomatal conductance and carbon assimilation during drought periods (Rust and Roloff, 2002). Previous studies indicated that oak sensitivity to water stress is especially high during spring and early summer (Bridge and Winchester, 2000; Siwecki and Ufnalski, 1998).

Several mechanisms may help explain the positive growth impact of average temperatures during the previous October (Fig. 3). It is likely that higher October temperatures lead to an extended period of physiological activity at the end of the growing season, which allows for more time to complete relocation of transportable assimilates from leaves to perennial parts of the tree. For sessile oak ( $Q$. petraea Mill.), Barbaroux and Bréda (2002) showed that maximum storage of reserves in the wood is reached in October. Similarly, a study of red oak ( $Q$. rubra L.) demonstrated that a peak in translocation of sugars from the leaves to the main stem occurred during late October (Xu and Griffin, 2007). A warmer October may, therefore, result in more carbohydrates being relocated to perennial tissues, making more nutrient and energy reserves available for growth during the next season. In addition, since the amount of non-structural carbohydrates in plant tissues is generally linked to the degree of frost tolerance (Parker, 1967; Sakai and Larcher, 1987; Thomas et al., 2004), a higher degree of translocation may increase the resistance of oak trees to low temperatures. A similar positive relationship between growth and previous October temperature was reported in pedunculate oaks in England (Fletcher, 1974). A study of old-growth oak forest in France (Lebourgeois et al. 2004) suggested that it is development of the earlywood which is the most strongly controlled by the environmental conditions of the previous autumn.

With the exception of previous year October temperature, the response function analysis showed little impact on the growth by weather during the dormant season. Apparently, during non-extreme years the weather in late autumn, winter and early spring exerts a weak control over oak growth. This suggests that even in the areas located close to the northern border of the European oak distribution range (Dahl, 1998), annual oak growth is not directly driven by conditions in the cold part of the season, but rather dynamics of water availability during the growth season. The amount of growth season precipitation, in turn, has been shown to be positively related to the strength of wintertime westerly flow across the North Atlantic (Kelly et al., 2002).

\subsection{Regional pointer years}

A striking feature of the pointer year list was a low proportion of trees representing even the most distinct growth anomalies, corresponding percentages for the nine major pointer years staying between 16.0 and $32.4 \%$. Kelly et al. (2002), using though a different algorithm to identify Europe-wide oak pointer years (termed in that study as "signature years"), reported three to four times higher percentages of oaks recording a pointer year. Clearly, the choice of distributional thresholds in this study (considering only $<5 \%$ and $>95 \%$ of ring-width distribution) affects the number of trees representing a pointer year. The low percentage of trees recording pointer years could result from the sub-regional variation in weather conditions (Raab and Vedin, 1995) superposed with variation in site properties.

The pattern of spatial correlation between percentage of trees recording pointer years and krigged values of climatic extremes changed from one year to another (Fig. 4). This indicated that it was sub-regional variation in the expression of weather extremes, and not site properties, which controlled the spatial pattern of the pointer year expressions.

The most widespread growth anomaly occurred in 1965 , when the annual growth increment of $32.4 \%$ of all trees fell below the lower $5 \%$ of the respective ring-width distributions. 
Spatial analyses showed a correlation between the pattern of the pointer year and weather anomaly in March of that year. A period of cold weather occurred on March the 30th 1965, when the intrusion of cold Arctic air masses resulted in a night frost covering most of southern Sweden (Anonymous, 1966). The association of negative March temperature anomalies with the occurrence of negative pointer years suggests that oak is sensitive to spring frosts (Tab. I). In southern Sweden, the occurrence of low air temperature during summer nights can cause severe damage to young oak shoots, leading to a substantial decrease in diameter growth (Barklund and Wahlström, 1998; Ståål, 1986). Similar results have been reported from other parts of Europe (Landmann et al., 1993; Selochnik and Kondrashova, 1989). Factors affecting pre-winter hardening of the trees may, therefore, be important for oak response to spring frosts. Warm winters tend to have a negative effect on the trees' ability to withstand sudden spells of low temperatures, owing to the high water content and status of carbohydrate reserves (Ståål, 1986). A recent study of cold hardiness across a range of oak species and site climatic conditions (Morin et al. 2007) indicates that variations in the concentrations of soluble carbohydrates, which control oak cold hardness, appear to be temperature-regulated. We speculate that the importance of pre-winter hardening might be reflected in the consistent positive correlation between growth during climatically non-extreme years and the previous year's October temperature (Fig. 3).

The most recent pointer year was recorded in 1992, which is known for one of the most extreme drought events in Sweden (Karlström, 1993) and as a drought year in other parts of Europe (Larsson-McCann, 1992). A high-pressure system developed over Scandinavia from May to July that year caused both positive temperature and negative precipitation anomalies over most of southern Sweden. Most of the climate stations in this region recorded zero precipitation for a continuous period of 36-56 days during the spring and summer months (Karlström, 1993). For the study area, the spatial pattern of this pointer year was the most consistent with June precipitation (Fig. 4), and to a lesser extent, with the previous year's temperatures in July. Apparently, water deficit resulting from elevated temperatures in the previous growth season was further enhanced by the deficit due to current year drought, spatial patterns of both variables being similar. Although an unusually high temperature was already recorded in January that year, the actual drought build-up began in May (Tab. I).

The growing period of 1956 was associated with a number of weather extremes (Fig. 4). A negative temperature anomaly in February appeared to be correlated with the spatial pattern of the pointer year expression (Tab. II); however, the result was not significant (empirical $p=0.265$, Tab. II), despite the high percentage $(87.8 \%)$ of re-sampled coefficients falling below zero. The temperature pattern in February of that year was a plausible explanation of the pointer year expression. This period of cold weather was reportedly caused by a spell of cold Arctic air from north-eastern Fennoscandia (Anonymous, 1957), resulting in air temperatures of -30 to $-32{ }^{\circ} \mathrm{C}$ in most of southern Sweden. The results of spatial correlation analyses for that year were, however, less conclusive than for 1965 and 1992.

Negative temperature anomalies in March occurred in three out of eight negative pointer years (1965, 1947 and 1940), and negative temperature anomalies in February occurred twice (1956 and 1940). Although spatial correlation between spring temperatures and growth anomalies was only clearly established for 1965, negative pointers were commonly associated with extremely low temperatures in late winter and spring (Tab. I). Such weather conditions normally develop during years with enhanced anticyclonicity in the Arctic circulation system, when blocking anticyclones define the weather patterns over Northern Europe (Mares et al., 2002). Association of negative pointers with such periods was reported previously on the pan-European scale (Kelly et al., 2002). Two positive pointer years (1882 and 1860) had monthly precipitation values reaching 83-94\% thresholds of their distribution for at least two summer months, confirming the positive impact of above-average precipitation on oak growth.

Spatial analyses of pointer years and climatic extremes appear to be a useful tool in identifying likely triggers of regional growth anomalies. These analyses may not necessarily produce definite results (e.g. Zierl, 2004) and generally require large and spatially distributed tree-ring datasets. They do, however, aid in disentangling growth-climate interactions on a sub-annual scale. In particular, spatial variation in pointer year expression, within the study sub-regions, may explain the low percentages of trees recording pointer years observed on the scale of the whole region. Taking 1965 as an example, the regional average for trees recording this year as a pointer was $32.4 \%$, with variation among sub-regions $(60.4 \%$ and $3.1 \%$, Fig. 4). Downscaling the analyses appears to be particularly useful in situations where one may expect a large withinregion variability of climatic factors. Furthermore, the region of southern Sweden is large enough to exhibit considerable variation in weather conditions during a particular growing season, and analyses on a sub-regional scale may provide a clearer picture of climate-growth interactions.

Accumulating larger and more spatially distributed data should be helpful in studying historical frequency of stressful climatic situations in oak. A strong correlation between the number of trees recording a pointer year and growth in the following years (Fig. 6) suggests that expression of pointer year, as depicted by standard dendrochronological methods, may help quantify the impact of these events on growth variation above-annual time scales. In studies of long-term growth trends, accounting for lag-effects of single pointer years may therefore provide a tool for better partitioning of high- and low-frequency signals in tree-ring chronologies.

\subsection{Future climate and oak growth}

It is of direct practical interest to relate the observed association of weather and growth to historic and future environmental variability. As in other parts of Europe (Thomas et al., 2002), oak in Sweden has been showing signs of decline and increased mortality since the 1980s (Drobyshev et al., 2007a; 
Sonesson, 1999), with the widespread pattern of decline pointing toward regional climate as one of the main factors negatively affecting the health of oak stands (Drobyshev et al., 2007b).

Our current knowledge of future variability in temperature and precipitation in Northern Europe does not provide a conclusive answer about oak growth trends in the future. Changes in water regime, one of the main drivers of oak growth dynamics, are of particular interest. In addition to a long-term increase in humidity over the last 4000-5000 years (Eronen et al., 2002), precipitation over northern Europe has increased by 10-40\% during the 20th century (Hanssen-Bauer and Forland, 2000). Over Fennoscandia changes in precipitation have also been observed over the past decades, with the regional climate becoming progressively more oceanic (Hanssen-Bauer and Forland, 2000; Lloyd-Hughes and Saunders, 2002). Climate projections suggest a continuation of this trend; however, most of the future precipitation increase is expected before and after summer. Climate simulations generally indicate drier summers in the future (Brabson et al., 2005; Rummukainen et al., 2001) with lower cloudiness and soil water content across Europe during the growing period (Giorgi et al., 2004). This trend may translate into reduced growth of oak and higher incidence of negative growth anomalies on an annual scale. No such trend has yet been documented: a pan-European study of historical dynamics of standardised precipitation indices (SPI) and the Palmer drought severity index (PDSI) has shown that the proportion of Europe experiencing extreme and/or moderate drought conditions has changed insignificantly during the 20th century (Lloyd-Hughes and Saunders 2002b).

As for the long-term pattern of temperature variation in Northern Europe, as depicted by instrumental records (Jones et al., 2002), the growth season might have been warmer before 1860 , indicating generally less favourable conditions for oak (see also the critical review of this data in Moberg et al., 2003). Some models also predict a general increase in October temperatures (Frich et al., 2002), which is positively correlated with oak growth (Fig. 3), and may result in higher prewinter translocation efficiency. A regional study of growing season changes in Fennoscandia (Hodga et al., 2006), based on the remotely-observed normalised difference vegetation index (NDVI), showed a delay in the end of the growing season during 1981-1998. This trend, which may represent a global phenomenon of a longer growing season in the Northern Hemisphere (Linderholm, 2006), could have a positive effect on oak pre-winter hardening in southern Sweden. Simultaneously, a considerable variability in temperature and precipitation regimes has been documented on decadal and centurial time scales (Alexander et al., 2006) and studies predict generally higher weather variability in the future (Schar et al., 2004), which may increase the incidence of environmentally stressful conditions.

Much of the discussion on future climate-growth interactions is centred around changes in the relative competitiveness of species (Bonn, 2000; Loehle and LeBlank, 1996; Piutti and Cescatti 1997), which may also have been an important driver of oak distribution dynamics in Europe since the last glacial period (Brewer et al., 2002). In this context, although oak appears to react strongly to water deficit during the growing season, its relative drought tolerance may be higher than in other hardwood and softwood species. A study of competition dynamics in mixed beech-oak stands in Germany revealed much lesser growth response of oak trees to drought as compared with European beech (Fagus sylvatica), which might reflect the differences in root systems of these two species (Bonn, 2000). Oak utilises a number of morphological and physiological adaptations for drought avoidance and drought tolerance (Dickson and Tomlinson, 1996), one of which is control of stomatal conductance. Interestingly, a comparative study of stomatal conductance response in seedlings of beech, chestnut (Castanea sativa Mill.) and oak trees has shown that oak may benefit from an increased ambient $\mathrm{CO}_{2}$ concentration (Heath, 1998). Oak can respond to an elevated $\mathrm{CO}_{2}$ concentration (ambient air enriched by $250 \mathrm{ppm} \mathrm{CO}_{2}$ ) by decreasing its stomatal conductance by approximately $50 \%$, resulting in a higher water-use efficiency than in the other two species.

\subsection{Comparison with European pointer years}

Water availability during the growing season appears to be the main factor controlling positive and negative growth anomalies on the European scale (Kelly et al., 2002) and during climatically "non-extreme" seasons in southern Sweden. In southern Sweden, the list of oak pointer years is, however, considerably different from the lists of pointer years in the central and southern part of the continent. Only two of the years listed by Kelly et al. (2002), the negative pointer years 1940 and 1956, were present on both lists, suggesting a rather regional pattern of growth anomalies in southern Swedish oaks. Southern Sweden lies at the edge of the area covered by the dataset used in the study of European pointers and was therefore represented by just a small proportion of all sites, the majority of them being centred around northern Germany southern Denmark, as well as the British Isles (Kelly et al., 2002). Negative temperature anomalies during winter-spring periods may be important determinants of oak pointer years in southern Sweden, while pointer years in central and western parts of Europe are largely a product of precipitation dynamics. In southern Sweden, precipitation appears to drive "average" growth dynamics, i.e. increment in climatically nonextreme years. With the exception of the extreme drought in 1992 , the most pronounced annual growth anomalies were probably caused by extremes in temperature and not in precipitation.

The lack of correspondence between pan-European and southern Swedish oak pointer years implies that in southern Sweden, the occurrence of pointer years is a product of regional climate variation and only partly reflects Arctic or North-Atlantic oscillation patterns, which are believed to be responsible for variations in water availability on the sub-continental scale (Briffa et al. 1994; Linderholm 2006; Lloyd-Hughes and Saunders, 2002). If this assumption is correct, the effects of low temperatures on oak growth should be incorporated in the regional modelling of growth and productivity dynamics under a changing climate. 
Acknowledgements: The study was kindly supported by the Carl Tryggers Stiftelse för Vetenskaplig Forskning, Foundation of Oscar and Lili Lamm Memory, Carl-Fredrik von Horns Foundation (The Royal Swedish Academy of Agriculture and Forestry), Godsförvaltaren vid Näsbyholm Stig Anderssons Foundation (grants to I. Drobyshev), Region Skåne Environment Foundation (grant to I. Drobyshev and K. Sonesson), and the Lidells Foundation (grant to K. Sonesson). We acknowledge the Laboratory for Wood Anatomy and Dendrochronology, Lund University, for providing us with additional oak chronologies. We thank the landowners who generously provided permission to sample and the Regional Board of Forestry, Södra Götaland, and J. Sörensen (Björnstorp och Svenstorps godsförvaltning) for logistic support. We thank Michelle Staney for linguistic help.

\section{REFERENCES}

Ahti T., Hämet-Ahti L., and Jalas J., 2004. Vegetation zones and their sections in northwestern Europe. Ann. Bot. Fenn. 5: 169-211.

Alexander L.V., Zhang X., Peterson T.C., Caesar J., Gleason B., Tank A.M.G.K., Haylock M., Collins, D., Trewin B., Rahimzadeh F., Tagipour A., Kumar K.R., Revadekar J., Griffiths G., Vincent L., Stephenson D.B., Burn J., Aguilar E., Brunet M., Taylor M., New M., Zhai P., Rusticucci M., and Vazquez-Aguirre J.L., 2006. Global observed changes in daily climate extremes of temperature and precipitation. J. Geophys. Res. 111. doi:10.1029/2005JD006290.

Aniol R., 1983. Tree-ring analysis using CATRAS. Dendrochronologia 1: $45-53$.

Anonymous, 1957. Årsbok 1956. 38. Stockholm, Sveriges Meteorologiska och Hydrologiska Institut.

Anonymous, 1966. Månadsöversikt över väderlek och vattentillgång 1965. Årsbok band 47. Del 1. Stockholm, Sveriges Meteorologiska och hydrologiska institut.

Anonymous, 2002. AcrMap 8.3. Environmental Research Institute. www.esri.com.

Baillie M.G.L., Hillam J., Briffa K.R., and Brown D.M., 1983. Redating the English art-historical tree-ring chronologies. Nature 315: 317-319.

Barbaroux C. and Bréda N., 2002. Contrasting distribution and seasonal dynamics of carbohydrate reserves in stem wood of adult ring-porous sessile oak and diffuse-porous beech trees. Tree Physiol. 22: 12011210 .

Barklund P. and Wahlström K., 1998. Death of oaks in Sweden since 1987. In: Cech T.L. and Hartman G.T.C. (Eds.), Disease/Environment Interaction in Forest Decline, Proceedings of a workshop of the working party Disease/Environment Interactions in Forest Decline IUFRO 7.02.06., 16th March-21st March 1998, Vienna, Austria, Federal Forest Research Centre, 193.

Bartholin T.S., 1975. Dendrochronology of oak in Southern Sweden. Tree-Ring Bull. 35: 25-29.

Biondi F. and Waikul K., 2004. DENDROCLIM2002: A C ${ }^{++}$program for statistical calibration of climate signals in tree-ring chronologies. Comput. Geosci. 30: 303-311.

Bonn S., 2000. Competition dynamics in mixed beech-oak stands and its modifications expected due to climate changes. Allg. Forst-u Jagdz. 171: $81-88$.

Brabson B.B., Lister D.H., Jones P.D., and Palutikof J.P., 2005. Soil moisture and predicted spells of extreme temperatures in Britain. J. Geophys. Res. Atmospheres 110: 1-9.

Brewer S., Cheddadi, R., de Beaulieu J.L., and Reille M., 2002. The spread of deciduous Quercus throughout Europe since the last glacial period. For. Ecol. Manage. 156: 27-48.

Bridge M.C. and Winchester V., 2000. An evaluation of standard oak tree growth in Ruislip woods, West London. Bot. J. Linnean Soc. 134: $61-71$.
Bridge M.C., Gasson P.E., and Cutler D.F., 1996. Dendroclimatological observations on trees at Kew and Wakehurst Place: Event and pointer years. Forestry 69: 263-269.

Briffa K.R. and Matthews J.A., 2002. ADVANCE-10K: a European contribution towards a hemispheric dendroclimatology for the Holocene. Holocene 12: 639-642.

Briffa K.R., Jones P.D., and Hulme M., 1994. Summer moisture variability across Europe, 1892-1991 - An analysis based on the palmer drought severity index. Int. J. Climatol. 14: 475-506.

Cook E.R. and Kairiukstis L.A., 1990. Methods of dendrochronology. Applications in the environmental sciences. International Institute of Applied System Analysis, Kluver Academic Publishers, Dordrecht, Netherlands.

Corcuera L., Camarero J.J., and Gil-Pelegrin E., 2004. Effects of a severe drought on Quercus ilex radial growth and xylem anatomy. Trees Struct. Funct. 18: 83-92.

Dahl E., 1998. The phytogeography of Northern Europe: British Isles, Fennoscandia and adjacent areas. Cambridge University Press.

Dickson R.E. and Tomlinson P.T., 1996. Oak growth, development and carbon metabolism in response to water stress. Ann. Sci. For. 53: 181-196.

Drobyshev I., Anderson S., and Sonesson K., 2007a. Crown condition dynamics of oak in southern Sweden 1988-1999. Environ. Monit. Assess. 134: 199-210.

Drobyshev I., Linderson H., and Sonesson K., 2007b. Relationship between crown condition and tree diameter growth in southern Swedish oaks. Environ. Monit. Assess. 128: 61-73.

Drobyshev I., Linderson H., and Sonesson K., 2007c. Temporal mortality pattern of pedunculate oaks in southern Sweden. Dendrochronologia 24: $97-108$.

Efron B. and Tibshirani R.J., 1994. An Introduction to the bootstrap. Chapman \& Hall.

Epron D. and Dreyer E., 1996. Starch and soluble carbohydrates in leaves of water-stressed oak saplings. Ann. Sci. For. 53: 263-268.

Eronen M., Zetterberg P., Briffa K.R., Lindholm M., Merilainen J., and Timonen M., 2002. The supra-long Scots pine tree-ring record for Finnish Lapland: Part 1, chronology construction and initial inferences. Holocene 12: 673-680.

Fletcher J.M., 1974. Annual rings in modern and medieval times. In: Morris M.G. and Perring F.H. (Eds.), The British Oak, Classey, Berkshire, pp. 80-97.

Fredén C.E., 2002. Geology. The National Atlas of Sweden. SNA Förlag, Stockholm.

Frich P., Alexander L.V., la-Marta P., Gleason B., Haylock M., Tank A.M.G.K., and Peterson T., 2002. Observed coherent changes in climatic extremes during the second half of the twentieth century. Clim. Res. 19: 193-212.

Fritts H.C., 1976. Tree rings and climate. Academic Press, New York, New York.

Giorgi F., Bi X.Q., and Pal J., 2004. Mean, interannual variability and trends in a regional climate change experiment over Europe. II: climate change scenarios (2071-2100). Clim. Dyn. 23: 839-858.

Girardin M.P., Tardif J., Flannigan M.D., and Bergeron Y., 2004. Multicentury reconstruction of the Canadian Drought Code from eastern Canada and its relationship with paleoclimatic indices of atmospheric circulation. Clim. Dyn. 23: 99-115.

Grissino-Mayer H.D., Holms R.L., and Fritts H.C. 1997. International tree-ring data bank program library manual. Laboratory of Tree-Ring Research, University of Arizona, Tuscon, Arizona.

Hanssen-Bauer I. and Forland E., 2000. Temperature and precipitation variations in Norway 1900-1994 and their links to atmospheric circulation. Int. J. Climatol. 20: 1693-1708. 
Heath J., 1998. Stomata of trees growing in $\mathrm{CO}_{2}$-enriched air show reduced sensitivity to vapour pressure deficit and drought. Plant Cell Environ. 21: 1077-1088.

Hodga K., Karlsen S., and Solheim I., 2006. Climatic change impact on growing season in Fennoscandia studied by a time series of NOAA AVHRR NDVI data. In: Proceedings of IGARSS 9-13 July 2001, Sydney, Australia.

Holmes R.L. 1999. Dendrochronological Program Library (DPL). Users Manual, Laboratory of Tree-Ring Research, University of Arizona, Tucson, Arizona, USA. http://www.ltrr.arizona.edu/pub/dpl/

Jones P.D., Briffa K.R., Osborn T.J., Moberg A., and Bergstrom H., 2002. Relationships between circulation strength and the variability of growing-season and cold-season climate in northern and central Europe. Holocene 12: 643-656.

Karlström C.E., 1993. Torka, skyfall och rekordsnö. Väder coh Vatten, SMHI 1: 2-7.

Kelly P.M., Leuschner H.H., Briffa K.R., and Harris I.C., 2002. The climatic interpretation of pan-European signature years in oak ringwidth series. Holocene 12, 689-694.

Landmann G., Becker M., Delatour C., Dreyer E., and Dupouey J.L. 1993. Oak dieback in France: historical and recent records, possible causes, current investigations. In: Zustand und Gefährdung der Laubwälder, Bayerische Akademie der Wissenschaften (Ed.), Rundgespräche der Kommission fur Ökologie 5. F.Pfeil, Munchen, Germany, pp. 97-113.

Larsson-McCann S., 1992. Övader över Uppland. Väder coh Vatten, SMHI July 1992. Norrköping.

Lebourgeois F., Cousseau G., and Ducos Y., 2004. Climate-tree-growth relationships of Quercus petraea Mill. stand in the Forest of Bercé ("Futaie des Clos", Sarthe, France). Ann. For. Sci. 61: 361-372.

Levy G., Becker M., and Duhamel D., 1992. A comparison of the ecology of pedunculate and sessile oaks - radial growth in the center and northwest of France. For. Ecol. Manage. 55: 51-63.

Linderholm H.W., 2006. Growing season changes in the last century. Agric. For. Meteorol. 137: 1-14.

Lindholm M., Eronen M., Timonen M., and Merilainen J., 1999. A ringwidth chronology of Scots pine from northern Lapland covering the last two millennia. Ann. Bot. Fenn. 36: 119-126.

Lloyd-Hughes B. and Saunders M.A., 2002. A drought climatology for Europe. Int. J. Climatol. 22: 1571-1592.

Loehle C. and LeBlanc D., 1996. Model-based assessments of climate change effects on forests: A critical review. Ecol. Model. 90, 1-31.

Mares I., Mares C., and Mihailescu M., 2002. NAO impact on the summer moisture variability across Europe. Physics and Chemistry of the Earth 27, 1013-1017.

Moberg A., Alexandersson H., Bergstrom H., and Jones P.D., 2003. Were southern Swedish summer temperatures before 1860 as warm as measured? Int. J. Climatol. 23: 1495-1521.

Morin X., Améglio T., Ahas R., Kurz-Besson C., Lanta V., Lebourgeois F., Miglietta F., and Chuine I., 2007. Variation in cold hardiness and carbohydrate concentration from dormancy induction to bud burst among provenances of three European oak species. Tree Physiol. 27: $817-825$

Nilsson N.E., 1996. Forests. Swedish National Atlas. SNA Förlag, Stockholm

Osipov V.V., 1989. Stand growth conditions in the Central Russian foreststeppe zone. In: Osipov V.V., Selochnik N.N., and Ilyushenko A.F., (Eds.), The state of oak forests in the forest-steppe zone, Nauka Publishing House, Moscow, pp. 5-18.

Osipov V.V. and Selochnik N.N., 1989. The state of oak forests in the Central Russian forest-steppe after materials of reconnoitring inspections in 1984-1987. In: Osipov V.V., Selochnik N.N., and Ilyushenko
A.F. (Eds.), The state of oak forests in the forest-steppe zone, Nauka Publishing House, Moscow, pp. 199-205.

Parker J., 1962. Seasonal changes in cold resistance and free sugars of some hardwood tree barks. For. Sci. 8: 255-262.

Pilcher J. and Gray S., 1982. The relationships between oak tree growth and climate in Britain. J. Ecol. 70, 297-304.

Piutti E. and Cescatti A., 1997. A quantitative analysis of the interactions between climatic response and intraspecific competition in European beech. Can. J. For. Res. 27: 277-284.

Prentice I.C., Sykes M.T., and Cramer W., 1991. The possible dynamicresponse of northern forests to global warming. Glob. Ecol. Biogeogr. Lett. 1: 129-135.

Raab B. and Vedin H., 1995. Klimat, sjöar och vattendrag. Sveriges National Atlas. SNA Förlag, Stockholm.

Ranius T. and Hedin J., 2001. The dispersal rate of a beetle, Osmoderma eremita, living in tree hollows. Oecologia 126: 363-370.

Rummukainen M., Raisanen J., Bringfelt B., Ullerstig A., Omstedt A., Willen U., Hansson U., and Jones C., 2001. A regional climate model for northern Europe: model description and results from the downscaling of two GCM control simulations. Clim. Dyn. 17: 339-359.

Rust S. and Roloff A., 2002. Reduced photosynthesis in old oak (Quercus robur): the impact of crown and hydraulic architecture. Tree Physiol. 22: 597-601.

Sakai A. and Larcher W., 1987. Frost survival of plants. Ecological Studies 62. Springer-Verlag, Berlin..

Sass-Klaassen U. and Hanraets E., 2006. Woodlands of the past - The excavation of wetland woods at Zwotte-Stadshagen (the Netherlands): Growth pattern and population dynamics of oak and ash. Netherlands Journal of Geosciences-Geologie en Mijnbouw 85: 61-71.

Schar C., Vidale P.L., Luthi D., Frei C., Haberli C., Liniger M.A., and Appenzeller C., 2004. The role of increasing temperature variability in European summer heatwaves. Nature 427: 332-336.

Schweingruber F.H., 1996. Tree rings and environment. Dendroecology. Paul Haupt Publishers, 609 p.

Schweingruber F.H. and Nogler P., 2003. Synopsis and climatological interpretation of Central European tree-ring sequences. Botanica Helvetica 113: 125-143.

Selochnik N.N. and Kondrashova N.K., 1989. The role of diseases in weakening the decline of oak forests. In: Osipov, V.V., Selochnik, N.N., Ilyushenko, A.F., et al. (Eds.), The state of oak forests in the forest-steppe zone, Nauka Publishing House, Moscow, pp. 115-137.

Siwecki R. and Ufnalski K., 1998. Review of oak stand decline with special reference to the role of drought in Poland. Eur. J. For. Pathol. 28: 99-112.

SNA, 2001. AcknowledgementsSveriges National Atlas CD-ROM. Lantmäteriverket.

Sonesson K., 1999. Oak decline in southern Sweden. Scand. J. For. Res. 14: $368-375$.

Ståål E., 1986. Eken i skogen och landskapet. Alvesta, Lindströms Bottryckeri i Alvesta. 127 p.

Stokes M.A. and Smiley T.L., 1968. An introduction to tree-ring dating. University of Chicago Press, Chicago, Illinois, USA. University of Chicago Press, Chicago, Illinois, USA.

Tessier L., Nola P., and Serrebachet F., 1994. Deciduous Quercus in the Mediterranean Region - Tree-ring/climate relationships. New Phytol. 126, 355-367.

Thomas F.M., Blank R., and Hartmann G., 2002. Abiotic and biotic factors and their interactions as causes of oak decline in Central Europe. For. Pathol. 32: 277-307. 
Thomas F.M., Meyer G., and Popp M., 2004. Effects of defoliation on the frost hardiness and the concentrations of soluble sugars and cyclitols in the bark tissue of pedunculate oak (Quercus robur L.). Ann. For. Sci. 61: 455-463.

Thompson D.W.J. and Wallace J.M., 1998. The Arctic Oscillation signature in the wintertime geopotential height and temperature fields. Geophys. Res. Lett. 25, 1297-1300.

Thompson D.W.J., Wallace J.M., and Hegerl G.C., 2000. Annular modes in the extratropical circulation. Part II: Trends. J. Clim. 13: 10181036.

Thuiller W., Lavorel S., Sykes M.T., and Araujo M.B., 2006. Using nichebased modelling to assess the impact of climate change on tree functional diversity in Europe. Divers. Distrib. 12: 49-60.
Tuomenvirta H., Drebs A., Førland E., Tveito O.E., Alexandersson H., Laursen E.V., and Jonsson T., 2001. Nordklim data set 1.0, description and illustrations. 08/01 KLIMA. Oslo, Norwegian Meteorological Institute.

Xu C.Y. and Griffin K.L., 2007. Seasonal variation in the temperature response of leaf respiration in Quercus rubra: foliage respiration and leaf properties. Funct. Ecol. 20: 778-789.

Zierl B., 2004. A simulation study to analyse the relations between crown condition and drought in Switzerland. For. Ecol. Manage. 188: $25-38$. 